\title{
Plasma Paraoxonase, Health, Inflammatory Conditions, and Liver Function in Transition Dairy Cows
}

\author{
M. Bionaz, ${ }^{1}$ E. Trevisi, L. Calamari, F. Librandi, A. Ferrari, and G. Bertoni ${ }^{2}$ \\ Istituto di Zootecnica, Facoltà di Agraria, Università Cattolica del Sacro Cuore, Via Emilia Parmense 84, Piacenza, Italy
}

\begin{abstract}
Paraoxonase (PON) is a liver protein with hydrolase activity that is released into the blood stream. Paraoxonase may serve as an index of liver function because it is drastically reduced in chronic liver damage. Sixtyseven periparturient dairy cows were used to evaluate the relationship between plasma PON, health problems, inflammatory conditions, and liver function. Baseline plasma PON concentrations during the first $30 \mathrm{~d}$ in milk (DIM) were retrospectively used to group cows into quartiles. Metabolic profile, lipid metabolites (e.g., nonesterified fatty acids, $\beta$-hydroxybutyrate), inflammatory indices (haptoglobin, ceruloplasmin), low and high density lipoprotein cholesterol, vitamin A, vitamin $\mathrm{E}$, reactive oxygen metabolites, total antioxidants, and PON in plasma were measured $2 \mathrm{wk}$ before to 8 wk after calving. Weekly milk yield, body condition score, and all health problems were recorded. After parturition (7 DIM), cows in the lower PON group had the lowest plasma concentrations of negative acute phase proteins compared with the higher PON group for retinol binding protein $(23.2 \pm 2.86$ vs. $36.0 \pm 2.96 \mu \mathrm{g} / \mathrm{dL}$ of vitamin A), albumin ( $31.6 \pm 0.73$ vs. $33.9 \pm 0.75 \mathrm{~g} /$ $\mathrm{L})$, total cholesterol ( $2.04 \pm 0.30$ vs. $2.45 \pm 0.42 \mathrm{mmol} /$ $\mathrm{L})$, and the highest concentrations of haptoglobin $(0.67$ vs. $0.24 \pm 0.03 \mathrm{~g} / \mathrm{L}$; positive acute phase protein) and globulins (37.2 vs. $32.3 \pm 1.4 \mathrm{~g} / \mathrm{L})$. Plasma bilirubin was highest in the cows ( 10.1 vs. $6.2 \pm 0.6 \mu \mathrm{mol} / \mathrm{L})$ in the lowest PON quartile. Plasma PON was negatively correlated with haptoglobin $(\mathrm{r}=-0.39)$ and bilirubin $(\mathrm{r}=$ -0.42 ) and positively correlated with retinol binding protein $(r=0.54)$, albumin $(r=0.38)$, and cholesterol $(\mathrm{r}=0.55)$ fractions. A total of $82.3 \%$ of cows in the lower quartile and no cows in the upper quartile experienced serious inflammation. Lower quartile cows produced $28.1 \pm 10.3 \mathrm{~kg}$ of milk/d; whereas upper quartile cows produced $38.3 \pm 7.7 \mathrm{~kg}$ of milk/d during the first 30
\end{abstract}

\footnotetext{
Received July 13, 2006.

Accepted November 30, 2006.

${ }^{1}$ Present address: Department of Animal Sciences, University of Illinois, 428 ASL, Urbana, IL 61801 (bionaz@uiuc.edu).

${ }^{2}$ Corresponding author: giuseppe.bertoni@unicatt.it
}

DIM. A reduction in the ability of the liver to cope with the increased metabolic demand near parturition in dairy cows can be diagnosed using changes in baseline plasma PON.

Key words: paraoxonase, liver function, periparturient dairy cow, inflammatory condition

\section{INTRODUCTION}

The possible role of an inflammatory response in the development of fatty liver in periparturient dairy cows, suggested by Calamari et al. (1994), has been highlighted recently (Ametaj et al., 2005; Bertoni et al., 2006). Normal parturition in dairy cows is characterized by inflammatory-like conditions (Cappa et al., 1989) that can produce oxidative stress (Turk et al., 2005). During inflammation, proinflammatory cytokines such as tumor necrosis factor alpha, IL-1, and IL6 are produced in large amounts by immune cells. These cytokines stimulate the liver to synthesize positive acute phase proteins (+APP), such as haptoglobin and ceruloplasmin (Fleck, 1989; Gruys et al., 1998). Concomitantly, cytokines impair hepatic synthesis of negative acute phase proteins (-APP), some of them important for normal liver metabolism. For instance, a disruption of apolipoprotein B100 synthesis might increase the risk of lipidosis (Itoh et al., 1997), particularly because dairy cows produce only small amounts of apolipoprotein B100 (Gruffat et al., 1997).

Paraoxonase (PON, aryldialkylphosphatase, EC 3.1.8.1) is a calcium-dependent ester hydrolase that catalyzes the hydrolysis of many xenobiotics (Ferré et al., 2002). The PON gene, PON1, is expressed primarily in the liver (Ferré et al., 2002). After synthesis, some of the PON remains inside the hepatocyte, and some of it is released into the blood where it binds to high density lipoprotein (HDL) by association with apolipoprotein A1 (Mackness et al., 1998). Although blood concentration of PON is relatively stable throughout the lifespan of an individual (Mackness et al., 1998), it is influenced by disease state, diet, and other environmental factors (Costa et al., 2003). For example, PON levels in the blood fall after serious insults such as atherosclerosis, myocardial infarction (Mackness et al., 1998), and 
chronic liver damage (Ferré et al., 2002). Paraoxonase is considered a -APP (James and Deakin, 2004). Its concentration is strongly reduced after LPS challenge (Feingold et al., 1998). Oxidative stress affects PON activity, and there is an inverse relationship between lipid peroxidation and PON (Aviram and Rosenblat, 2004).

Studies of PON in bovine liver are limited. Turk et al. $(2004,2005)$ investigated the activity of PON in pregnant, early lactating, and late lactating dairy cows. They suggested that the observed reduction in PON activity immediately postpartum may be due to 1 ) fat mobilization and triglyceride deposition in liver cells, which cause liver damage or dysfunction (Turk et al., 2004); 2) reduction in blood cholesterol HDL (Turk et al., 2005); 3) an increase in oxidative stress (Turk et al., 2004, 2005); or 4) a combination of these. In another study, Zech et al. (1999) found no correlation between the activity of the enzyme in serum and in liver.

The evidence that PON synthesis is affected by several pathophysiological conditions (e.g., serious diseases, LPS, or proinflammatory cytokine challenges), and that these phenomena frequently occur in the transition period, suggests that PON plays a role around parturition. The objective of this study was to determine the relationship between plasma PON activity and health problems, inflammatory conditions, plasma metabolic measures, and milk yield; and to evaluate the possibility of utilizing plasma PON as an index of liver function (i.e., synthesis of proteins involved in usual hepatic activities) in periparturient dairy cows.

\section{MATERIALS AND METHODS}

\section{Animals}

Sixty-seven Friesian dairy cows from 2 herds of the Italian Po Valley (herd A, $\mathrm{n}=36$; herd $\mathrm{B}, \mathrm{n}=31$ ) were monitored during the transition period and during early lactation. Cows in each herd were kept in freestalls in 2 groups (dry and lactating). Most of the cows in herd A were multiparous (35 out of 36 ), whereas in herd B, 14 cows were primiparous and 17 cows were multiparous. Cows calved in the pens of dry cows; therefore, they did not receive any diet supplementation before parturition. The cows were moved into the lactation pen immediately after calving.

All the cows were fed a TMR once daily. The diets differed between herds and production groups (Table 1). The dietary protein content in the close-up period and dietary energy and protein contents during lactation were lower than usually suggested, but they were similar to typical diets of lactating cows in Italy.

\section{Blood Collection and Analysis}

Blood samples were collected weekly beginning 2 to 3 wk before the expected date of parturition, within 24 $\mathrm{h}$ after parturition (0 DIM), and weekly for the first 2 mo of lactation. In the morning, before feeding, blood samples were collected from the jugular vein into evacuated tubes containing Li-heparin as an anticoagulant (Vacuette, Kremsmünster, Austria). A small amount of blood was used for hematocrit determination (Centrifugette 4203, ALC International Srl, Cologno Monzese, Italy); the remainder was centrifuged at $3,500 \times g$ for $15 \mathrm{~min}$, and the plasma was frozen $\left(-20^{\circ} \mathrm{C}\right)$ in several fractions until further analysis.

Blood metabolites were analyzed at $37^{\circ} \mathrm{C}$ by a clinical auto-analyzer (ILAB 600, Instrumentation Laboratory, Lexington, MA). Glucose, total protein, albumin, total cholesterol, total bilirubin, triglycerides, creatinine, urea, $\mathrm{Ca}, \mathrm{P}, \mathrm{Mg}$, aspartate aminotransferase (AST/ GOT), and $\gamma$-glutamyl transpeptidase (GGT) were determined using kits purchased from Instrumentation Laboratory (IL Test). Globulin was calculated as the difference between total protein and albumin. Electrolytes $\left(\mathrm{Na}^{+}, \mathrm{K}^{+}\right.$, and $\left.\mathrm{Cl}^{-}\right)$were detected by the potentiometer method (Ion Selective Electrode connected to ILAB 600). Zinc, low-density lipoprotein cholesterol (C-LDL), high-density lipoprotein cholesterol (C-HDL), phospholipids, and NEFA were determined by commercial kits (Wako Chemicals GmbH, Neuss, Germany). Haptoglobin, BHBA, and ceruloplasmin were analyzed using methods described by Bertoni et al. (1998), adapting them to the ILAB 600 conditions.

Plasma vitamins A and $\mathrm{E}$ were extracted with hexane and analyzed by reverse-phase HPLC using Spherisorb ODS-2, $3 \mu \mathrm{m}$, in a $150 \times 4.6 \mathrm{~mm}$ column (Alltech, Deerfield, IL); a UV detector set at $325 \mathrm{~nm}$ (for vitamin A) or $290 \mathrm{~nm}$ (for vitamin E); and 80:20 methanol:tetrahydrofurane as the mobile phase.

Total plasma reactive oxygen metabolites $(\mathbf{R O M})$ and total antioxidants were measured only on samples taken from -7 to $+28 \mathrm{~d}$ from calving. The 2 analytical methods are patented by Diacron International s.r.l. (Grosseto, Italy). The ROM were expressed in milligrams of hydrogen peroxide per $100 \mathrm{~mL}$ of plasma, whereas the total antioxidants were expressed as micromoles of $\mathrm{HClO} / \mathrm{mL}$ in excess after reaction.

Plasma PON activity was measured by adapting the method of Ferré et al. (2002) to the ILAB 600. Briefly, $8 \mu \mathrm{L}$ of plasma added to $125 \mu \mathrm{L}$ of ultrapure water and $125 \mu \mathrm{L}$ of assay buffer were incubated at $37^{\circ} \mathrm{C}$. The assay buffer was composed of glycine buffer $(0.05 \mathrm{~m} M$, $\mathrm{pH}$ 10.5) containing $1 \mathrm{~m} M$ of paraoxon-methyl (SigmaAldrich, Seelze, Germany), $1 \mathrm{mM}$ of $\mathrm{CaCl}_{2}$ and without $\mathrm{NaCl}$. The rate of hydrolysis of paraoxon to $p$-nitrophe- 
Table 1. Ingredients and main chemical and nutritional traits (\% of DM) of the diets utilized as TMR for close-up and lactating cows of the 2 herds

\begin{tabular}{|c|c|c|c|c|}
\hline \multirow[b]{3}{*}{ Component } & \multicolumn{4}{|c|}{ Herd } \\
\hline & \multicolumn{2}{|c|}{ A } & \multicolumn{2}{|c|}{ B } \\
\hline & $\begin{array}{l}\text { Close-up } \\
\text { dry cows }\end{array}$ & $\begin{array}{c}\text { Lactating } \\
\text { cows }\end{array}$ & $\begin{array}{l}\text { Close-up } \\
\text { dry cows }\end{array}$ & $\begin{array}{c}\text { Lactating } \\
\text { cows }\end{array}$ \\
\hline & & - & 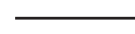 & - \\
\hline \multicolumn{5}{|l|}{ Ingredient } \\
\hline Grass hay & 75.00 & 3.73 & 43.46 & 7.04 \\
\hline Alfalfa hay & 2.89 & 14.90 & - & 10.87 \\
\hline Corn silage & 5.80 & 29.84 & 22.05 & 35.09 \\
\hline Grass silage & - & - & - & 4.58 \\
\hline Wheat straw & - & - & 11.08 & - \\
\hline Cottonseed & - & - & - & 5.41 \\
\hline Ground shelled corn & 4.68 & 24.11 & - & 17.77 \\
\hline Soybean meal & - & - & - & 9.02 \\
\hline Soybean seed & 1.05 & 5.40 & - & - \\
\hline Beet pulp & 0.71 & 3.67 & - & - \\
\hline Commercial concentrate & 9.87 & 18.35 & 23.41 & 9.81 \\
\hline Calcium soap of palm oil & - & - & - & 0.41 \\
\hline \multicolumn{5}{|l|}{ Chemical } \\
\hline $\mathrm{NE}_{\mathrm{L}}, \mathrm{Mcal} / \mathrm{kg}$ & 1.25 & 1.59 & 1.29 & 1.55 \\
\hline $\mathrm{CP}, \%$ of $\mathrm{DM}$ & 10.16 & 15.10 & 9.17 & 15.00 \\
\hline
\end{tabular}

nol was measured by monitoring the increase in absorbance at $405 \mathrm{~nm}$, using a molar extinction coefficient of $18,050 \mathrm{~L} \cdot \mathrm{mol}^{-1} \cdot \mathrm{cm}^{-1}$ as suggested by Feingold et al. (1998). The unit of PON activity (U/mL) is defined as $1 \mathrm{nmol}$ of $p$-nitrophenol formed per minute under the assay conditions.

\section{Milk Yield, BCS, and Health Problems}

Individual milk yield was monitored weekly after parturition. Because groups differed in parity, 305-d milk yield was obtained by transforming data to mature equivalent. The BCS was evaluated weekly until the 63 DIM according to a 5-point scale (Agricultural Development and Advisory Service of United Kingdom). All health problems affecting the animals during the first month of lactation were recorded; moreover, for cows with or without clinical symptoms, an increase of haptoglobin concentration and a large decrease of milk yield (over $0.3 \mathrm{~g} / \mathrm{L}$ and contemporary $20 \%$ reduction of milk, respectively) were used to identify cows affected by a serious inflammatory response.

\section{Data Handling and Groups}

Cows were retrospectively grouped in quartiles based on average PON activity during the first month of lactation. The use of quartiles in the formation of groups has the advantage of providing greater separation between cows with high differences in PON activity. Groups were defined as upper (UP, $\mathrm{n}=17$ ), the cows belonging to the quartile with the highest PON activity during the first month of lactation; upper intermediate (INUP, $\mathrm{n}=16$ ); lower intermediate (INLO, $\mathrm{n}=17$ ); and lower quartile $(\mathbf{L O}, \mathrm{n}=17)$ of PON activity. Herd A contained 14 cows in UP, 12 in INUP, 4 in INLO, and 6 in LO, whereas herd B contained 3 cows in UP, 4 in INUP, 13 in INLO, and 11 in LO.

\section{Statistical Analyses}

Data measured over time (BCS, milk yield, and plasma components) within the period of interest were aggregated according to DIM: $-14,-7,0,7,14,21,28$, 42 , and $63 \mathrm{~d}$ (values except 0 correspond to the real day $\pm 1 \mathrm{~d}$ ). These data were subjected to ANOVA using the REPEATED statement in the MIXED procedure of SAS (SAS Inst. Inc., Cary, NC, release 8.0). The statistical model included the fixed effect of group (UP, INUP, INLO, LO), DIM (-14, -7, 0, 7, 14, 21, 28, 42, 63), and group $\times$ DIM interaction. The random variables were herd and cow within group ( $\mathrm{n}=17$ for UP, $\mathrm{n}=16$ for INUP, $n=17$ for INLO, $n=17$ for LO). Each variable analyzed was subjected to 3 covariance structures: autoregressive order, compound symmetry, and spatial power. Using the largest Akaike information criterion and Schwarz Bayesian criterion, the spatial power was the covariance structure that fit the model best. The same model, including parity (primiparous, multiparous) and parity $\times$ group interaction, and using cow within group and parity as blocks, was used to evaluate the difference in each parameter between parity in herd $\mathrm{B}$ (primiparous, $\mathrm{n}=14$; multiparous, $\mathrm{n}=17$ ). Mature equivalent milk yield between groups was analyzed us- 
ing ANOVA, with group as a fixed factor and herd as a block. In addition, Pearson correlations between PON and the other blood measures were calculated for the entire period, using PROC CORR of SAS.

Prevalence of health problems recorded during the study were evaluated by $\chi^{2}$ analysis (PROC FREQ of SAS) to determine whether prevalence differed among groups. Statistical significance was designated as $P<$ 0.05 .

\section{RESULTS}

\section{PON Activity}

General Behavior. Overall, mean $( \pm \mathrm{SD}) \mathrm{PON}$ was $66.4 \pm 21.6 \mathrm{U} / \mathrm{mL}$ (range 21.3 to $147.6 \mathrm{U} / \mathrm{mL}$ ) with a pattern characterized by a significant decrease before parturition $(62.9 \pm 14.7$ vs. $56.3 \pm 15.8 \mathrm{U} / \mathrm{mL}$ at -14 DIM and at parturition, respectively), and a nadir at 7 $\operatorname{DIM}(54.3 \pm 22.1 \mathrm{U} / \mathrm{mL}$; Figure 1$)$. Thereafter, the activity of PON continuously increased to 63 DIM (82.4 \pm $19.3 \mathrm{U} / \mathrm{mL} ; P<0.01)$.

Difference Between Groups. The values of PON during the first month of lactation were $92.0 \pm 19.8$, $67.8 \pm 13.0,54.3 \pm 11.7$, and $43.8 \pm 12.7 \mathrm{U} / \mathrm{mL}$ for UP, INUP, INLO, and LO, respectively. The UP group did not significantly decrease in PON from -14 DIM to parturition, but PON increased during the first $2 \mathrm{wk}$ of lactation. The other groups declined in PON from -14 through 7 DIM, with a subsequent increase for the following 2 to $3 \mathrm{wk}$ (group effect, $P<0.01$; group $\times$ time interaction, $P<0.01$ ).

Parity and PON. Parity had no effect on PON in herd B $(58.6 \pm 20.8$ vs. $57.7 \pm 19.1 \mathrm{U} / \mathrm{mL}$ in primiparous and multiparous cows, respectively). Parity $\times$ group interaction was not statistically significant. Group UP was composed of 15 multiparous (ML) and 2 primiparous (PR) cows; INUP contained $14 \mathrm{ML}$ and $2 \mathrm{PR}$ cows; INLO contained $10 \mathrm{ML}$ and $7 \mathrm{PR}$ cows; and LO contained $13 \mathrm{ML}$ and $4 \mathrm{PR}$ cows.

Standardized PON Activity (PON/C-HDL). Because of the close physiological relationship between PON and HDL (Bin Ali et al., 2003), PON activity was expressed as units per millimole of C-HDL (PON/CHDL), which represents HDL-standardized PON activity (Turk et al., 2004). The PON/C-HDL pattern in each group is in Figure 1. Ratios were higher in the week prior to parturition $(47.1 \pm 22.8 \mathrm{U} / \mathrm{mmol})$ than at 63 DIM $(33.3 \pm 15.8 \mathrm{U} / \mathrm{mmol})$. The PON/C-HDL exhibited a general decrease after parturition and during the first month of lactation, and thereafter tended to be stable and similar between groups (group effect, $P<0.01$; group $\times$ time interaction, $P<0.05$ ).

PON and Blood Indices of Inflammation and Oxidative Status. The responses of haptoglobin and globulin for each group are in Figure 1. Both showed similar patterns across all groups, but the increase occurring at parturition, shorter for haptoglobin (7 DIM) and more prolonged for globulin (21 DIM), was significantly more pronounced in LO than in UP. Differences were not significant for haptoglobin at 42 DIM. There was a group effect for haptoglobin $(P<0.05)$; globulin showed a group effect $(P<0.05)$ but not a group $\times$ time interaction. Ceruloplasmin (data not shown) did not differ between groups.

The response of ROM for each group is in Figure 1. The ROM was greater in LO than in UP at parturition through d 14 postpartum. There was an overall group effect for ROM $(P<0.05)$ but no group $\times$ time interaction. Total antioxidants (data not shown) did not result in differences among groups. The data for plasma vitamin $\mathrm{E}$ are in Table 2.

PON and Blood Liver Indices. We have considered 2 main indices of liver function (Tennant, 1997); those representing synthesis of proteins and bilirubin clearance and those representing release of enzymes in response to liver cell damage. Among the former, responses and significant differences for albumin, retinol binding protein (RBP, reported as vitamin A), and lipoprotein fractions (total cholesterol, C-LDL, C-HDL, and phospholipids) are in Table 2. Before parturition nonsignificant differences were observed for vitamin A, albumin, and lipoprotein fractions. At parturition and immediately thereafter, these measures decreased with a nadir at parturition or within the first 14 DIM. The reduction was more pronounced in the $\mathrm{LO}$ than in the UP group; thus, the levels for albumin, vitamin A, total cholesterol, and C-LDL became significantly different at 7 or 14 DIM, or both. In contrast, differences in CHDL and phospholipids concentrations were not apparent. Albumin, RBP, cholesterol, and C-LDL increased after the first week of lactation, but the values in groups LO, INLO, and INUP remained lower than in UP almost to the end of the study (63 DIM).

Total bilirubin (Figure 1) was not different between groups at $14 \mathrm{~d}$ before parturition. Yet, it showed a sharp increase immediately after parturition. Thereafter, bilirubin decreased, but the values remained higher $(P<$ $0.05)$ in the LO group than in UP until 14 DIM. At 28 DIM, values were close to prepartum levels, and no difference was observed between groups. Bilirubin exhibited an overall group effect $(P<0.01)$ but not a group $x$ time interaction.

The enzymes released in response to liver cell damage, i.e., GOT/AST and GGT (despite not being specific to the liver), did not differ between groups (data not shown).

PON and Blood Metabolic Indices. Blood glucose, NEFA, and BHBA (Figure 2) were not different between 

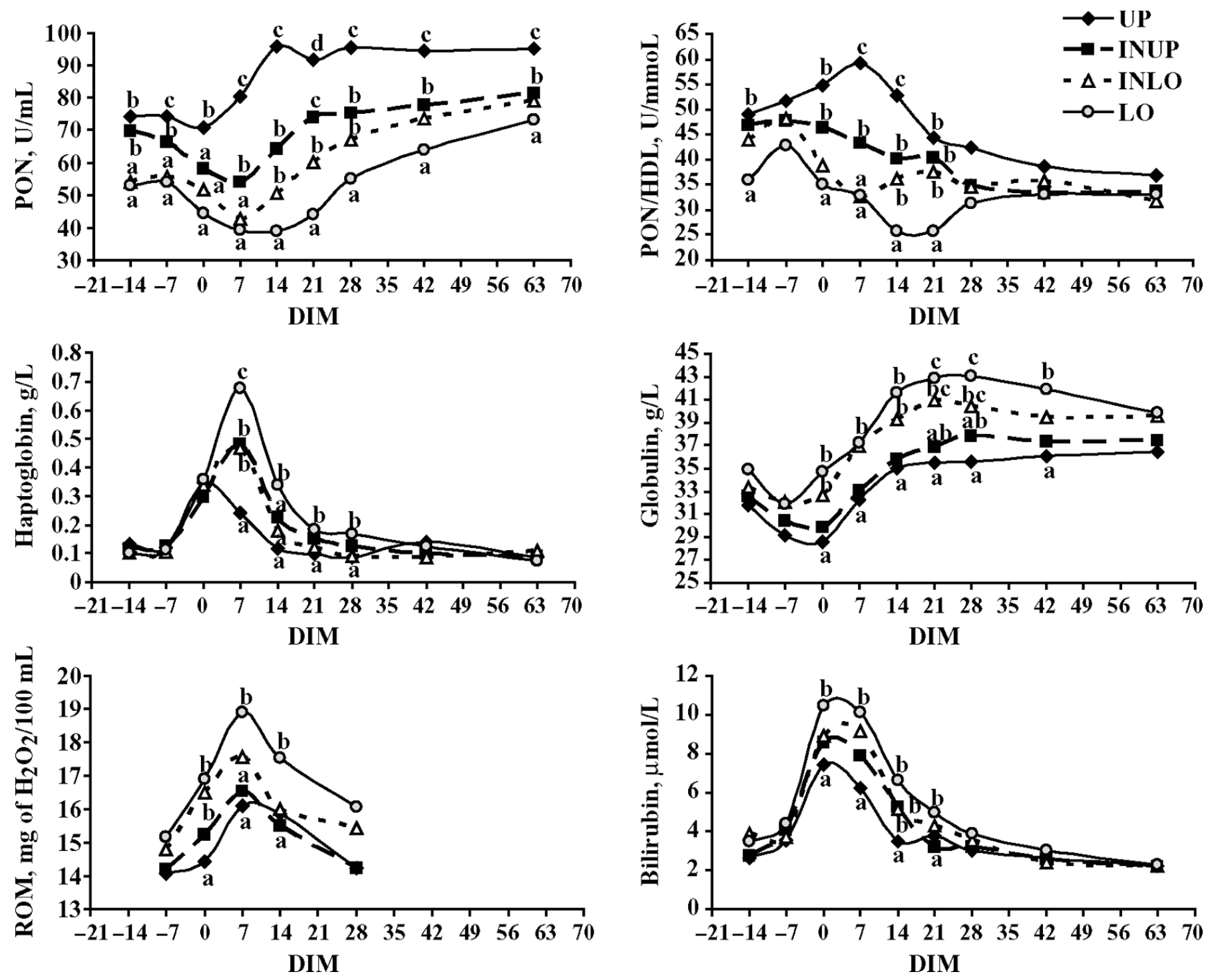

Figure 1. Patterns of baseline paraoxonase (PON) activity (SEM $=2.6)$, baseline PON activity measured as units per millimole of high density lipoproteins $(\mathrm{C}-\mathrm{HDL}$; $\mathrm{SEM}=6.5)$, haptoglobin $(\mathrm{SEM}=0.03)$, globulin $(\mathrm{SEM}=1.4)$, reactive oxygen metabolites $(\mathrm{ROM}$; $\mathrm{SEM}=1.0)$, and total bilirubin (SEM = 0.6) in plasma of cows grouped in quartiles according to baseline paraoxonase activity observed during the first month of lactation: upper (UP), upper intermediate (INUP), lower intermediate (INLO), and lower (LO) quartile. ${ }^{\mathrm{a}-\mathrm{c}} \mathrm{A}$ significant difference between groups at the same DIM is shown by letters; $P<0.05$.

groups. The group $\times$ time effect was not significant for these 3 measures. Urea exhibited a group effect $(P<$ 0.05); UP had the highest concentration of blood urea (Figure 2) compared with LO just after parturition (3.93 \pm 0.12 vs. $3.30 \pm 0.12 \mathrm{mmol} / \mathrm{L}$ ), and UP had higher concentrations from 21 to $42 \mathrm{DIM}$, but no group $\times$ time effect. Creatinine was not different. The overall means were $92.7,89.7,86.7$ and $86.8 \mu \mathrm{mol} / \mathrm{L}$ for UP, INUP, INLO, and LO, respectively $(\mathrm{SEM}=4.0)$.

PON and Blood Minerals. The overall calcium (Figure 2) group effect was not significant, and the group $\times$ time interaction was not significant $(P=0.07)$. Magne- sium (Figure 2) was not significantly different by group $(P=0.06)$; no group $\times$ time interaction was observed. Plasma $K$ (data not shown) differed significantly by group $(P<0.05)$. The group $\times$ time interaction was not significant. The LO group had significantly lower K concentrations than did the UP group just before parturition and at 21 DIM. Zinc, sodium, chloride, and phosphorus did not differ between groups (data not shown).

\section{Health Problems, BCS, and Milk Yield}

Recorded health problems during the first month of lactation are in Table 3. As the concentration of PON 
Table 2. Trend of plasma vitamin E and plasma indices of usual liver synthesis in group of upper (UP), upper intermediate (INUP), lower intermediate (INLO) and lower (LO) quartiles of baseline paraoxonase (PON) activity during late pregnancy and the first 2 mo of lactation

\begin{tabular}{|c|c|c|c|c|c|c|c|c|c|c|c|}
\hline Index ${ }^{1}$ & Group & \multicolumn{10}{|c|}{ Day from parturition (DIM) } \\
\hline Vitamin E, $\mu \mathrm{g} / \mathrm{mL}$ & UP & 2.73 & 2.54 & 2.09 & 1.86 & 2.40 & 2.96 & 3.47 & 4.10 & 4.94 & 0.38 \\
\hline \multirow{2}{*}{$\begin{array}{l}\mathrm{GE} ; P=0.81 \\
\mathrm{G} \times \mathrm{T} ; P=0.68\end{array}$} & INLO & 2.85 & 2.76 & 2.36 & 1.80 & 2.24 & 2.88 & 3.35 & 4.27 & 4.85 & 0.31 \\
\hline & $\mathrm{LO}$ & 3.16 & 2.91 & 2.35 & 1.86 & 2.15 & 2.68 & 3.19 & 3.85 & 4.57 & 0.33 \\
\hline Vitamin A, $\mu \mathrm{g} / 100 \mathrm{~mL}$ & UP & 43.8 & 37.6 & 27.2 & $36.0^{\mathrm{b}}$ & $45.7^{\mathrm{c}}$ & $49.8^{\mathrm{b}}$ & $52.5^{\mathrm{b}}$ & 56.0 & $62.7^{\mathrm{b}}$ & 2.96 \\
\hline \multirow[t]{2}{*}{ Albumin, g/L } & UP & 35.6 & 34.7 & 35.7 & $33.9^{\mathrm{b}}$ & $34.6^{\mathrm{b}}$ & $34.9^{\mathrm{b}}$ & $35.3^{\mathrm{c}}$ & $35.6^{\mathrm{b}}$ & $35.5^{\mathrm{b}}$ & 0.75 \\
\hline & INUP & 35.0 & 34.8 & 34.9 & $32.1^{\mathrm{a}}$ & $32.3^{\mathrm{a}}$ & $32.9^{\mathrm{a}}$ & $33.4^{\mathrm{b}}$ & $33.8^{\mathrm{a}}$ & $34.5^{\mathrm{ab}}$ & 0.75 \\
\hline \multirow{2}{*}{$\begin{array}{l}\mathrm{GE} ; P<0.01 \\
\mathrm{G} \times \mathrm{T} ; P<0.05\end{array}$} & INLO & 34.2 & 33.9 & 34.5 & $31.2^{\mathrm{a}}$ & $31.3^{\mathrm{a}}$ & $31.5^{\mathrm{a}}$ & $32.1^{\mathrm{ab}}$ & $33.8^{\mathrm{a}}$ & $34.9^{\mathrm{ab}}$ & 0.74 \\
\hline & LO & 35.6 & 33.9 & 34.8 & $31.6^{\mathrm{a}}$ & $31.0^{\mathrm{a}}$ & $31.1^{\mathrm{a}}$ & $31.0^{\mathrm{a}}$ & $32.9^{\mathrm{a}}$ & $33.4^{\mathrm{a}}$ & 0.73 \\
\hline \multirow[t]{2}{*}{ Cholesterol, $\mathrm{mmol} / \mathrm{L}$} & UP & 2.76 & 2.53 & 2.19 & $2.45^{\mathrm{b}}$ & $3.28^{\mathrm{c}}$ & $4.03^{\mathrm{b}}$ & $4.69^{b}$ & $5.52^{\mathrm{b}}$ & $6.22^{\mathrm{b}}$ & 0.42 \\
\hline & INUP & 2.55 & 2.40 & 2.04 & $2.08^{\mathrm{a}}$ & $2.76^{\mathrm{b}}$ & $3.43^{\mathrm{ab}}$ & $3.99^{\mathrm{ab}}$ & $4.65^{\mathrm{a}}$ & $5.08^{\mathrm{a}}$ & 0.36 \\
\hline \multirow{2}{*}{$\begin{array}{l}\mathrm{GE} ; P=0.17 \\
\mathrm{G} \times \mathrm{T} ; P=0.05\end{array}$} & INLO & 0.66 & 0.65 & $0.67^{\mathrm{b}}$ & $0.53^{\mathrm{b}}$ & $0.59^{\mathrm{b}}$ & 0.67 & $0.81^{\mathrm{ab}}$ & $0.85^{\mathrm{a}}$ & $0.95^{\mathrm{a}}$ & 0.23 \\
\hline & LO & 0.64 & 0.58 & $0.58^{\mathrm{ab}}$ & $0.47^{\mathrm{b}}$ & $0.52^{\mathrm{ab}}$ & 0.57 & $0.66^{\mathrm{a}}$ & $0.79^{\mathrm{a}}$ & $0.99^{\mathrm{ab}}$ & 0.23 \\
\hline \multirow[t]{2}{*}{ C-HDL, mmol/L } & UP & 1.47 & 1.37 & 1.22 & 1.33 & 1.85 & 2.17 & 2.41 & 2.69 & 2.90 & 0.41 \\
\hline & INUP & 1.46 & 1.38 & 1.26 & 1.20 & 1.65 & 1.95 & 2.29 & 2.51 & 2.78 & 0.41 \\
\hline \multirow{2}{*}{$\begin{array}{l}\mathrm{GE} ; P=0.77 \\
\mathrm{G} \times \mathrm{T} ; P=0.21\end{array}$} & INLO & 1.54 & 1.58 & 1.58 & 1.46 & 1.68 & 1.91 & 2.19 & 2.29 & 2.76 & 0.41 \\
\hline & LO & 1.56 & 1.45 & 1.35 & 1.27 & 1.55 & 1.78 & 1.96 & 2.24 & 2.74 & 0.41 \\
\hline \multirow[t]{2}{*}{ Phospholipids, mg/100 mL } & UP & 70.8 & 64.5 & 49.8 & 68.5 & 90.6 & 111.0 & 129.5 & 149.9 & 163.8 & 26.4 \\
\hline & INUP & 68.6 & 67.0 & 47.6 & 61.4 & 86.2 & 101.2 & 117.9 & 129.6 & 145.3 & 26.4 \\
\hline $\mathrm{GE} ; P=0.66$ & INLO & 78.1 & 82.6 & 67.0 & 75.8 & 84.6 & 99.5 & 114.9 & 126.3 & 147.7 & 26.3 \\
\hline $\mathrm{G} \times \mathrm{T} ; P=0.12$ & LO & 78.9 & 74.1 & 57.2 & 65.3 & 76.6 & 91.3 & 104.7 & 123.6 & 147.5 & 26.3 \\
\hline
\end{tabular}

${ }^{\mathrm{a}-\mathrm{c}}$ For each blood parameter, a significant difference between groups at the same DIM is shown by letters; $P<0.05$.

${ }^{1} \mathrm{GE}$ is the overall group effect; $\mathrm{G} \times \mathrm{T}$ is the group $\times$ time interaction effect.

increased, the frequency of serious inflammation decreased $(P<0.01)$. The herds showed a similar frequency of total health problems $(47.2 \mathrm{vs} .58 .1 \%$ for herds $\mathrm{A}$ and $\mathrm{B}$, respectively) and serious inflammatory phenomena (36.1 vs. $48.4 \%$ for herds A and B, respectively).

The BCS (Figure 3) was not affected by group, and there was no significant group $\times$ time interaction effect $(P=0.1)$.

The overall mean mature equivalent milk production for $305 \mathrm{~d}$ was $8,900 \mathrm{~kg} / \mathrm{yr}$. Cows in UP produced significantly more milk than cows in INLO and LO (mean \pm SD: $10,090 \pm 1,504$ vs. $8,185 \pm 1,947$ and $8,119 \pm 2,042$ $\mathrm{kg} / \mathrm{year}$, in UP, INLO, and LO respectively; $P<0.05$ ). The INUP group had an intermediate milk yield $(9,037$ $\pm 1,648 \mathrm{~kg} / \mathrm{yr}$ ). Milk production during the first month of lactation is in Figure 3; there was a group effect, but not a group $\times$ time interaction.

\section{DISCUSSION}

\section{General Discussion of PON Data}

The values of PON that we observed in the cows at the end of pregnancy and in the early lactation, within a range of 20 to $150 \mathrm{U} / \mathrm{mL}$, may not represent the full range of PON values in dairy cattle because we have assessed only a particular period of lactation (end of pregnancy and first 2 mo of lactation). In addition, the activity of PON was lower than that of Turk et al. (2004): $450 \mathrm{U} / \mathrm{L}$ for postpartum and $750 \mathrm{U} / \mathrm{L}$ for late lactating dairy cows. Turk reported the data in international units corresponding to micromoles per minute (R. Turk, personal communication), whereas our values were expressed in nanomoles per minute; their values can be converted to $\mathrm{U} / \mathrm{mL}$ ( 450 and $750 \mathrm{U} / \mathrm{mL}$, respectively) for the purpose of comparison. The differences between the values could be due to the differences in analytical methods. We used the baseline value of PON $\left(\mathrm{CaCl}_{2}\right)$, whereas the values of Turk et al. (2004) correspond to the salt-stimulated activity (by $1 \mathrm{~m} M$ of $\mathrm{NaCl}$; Ferré et al., 2002). In addition, the effect of differences between plasma (Li-heparin) and serum, as suggested by Mackness (1998), can be excluded because the 2 materials taken simultaneously from 15 cows showed identical results (mean of $99.0 \mathrm{U} / \mathrm{mL}$ and $\mathrm{SEM}=2.26$; $\left.\mathrm{R}^{2}=0.98, P<0.001\right)$. 

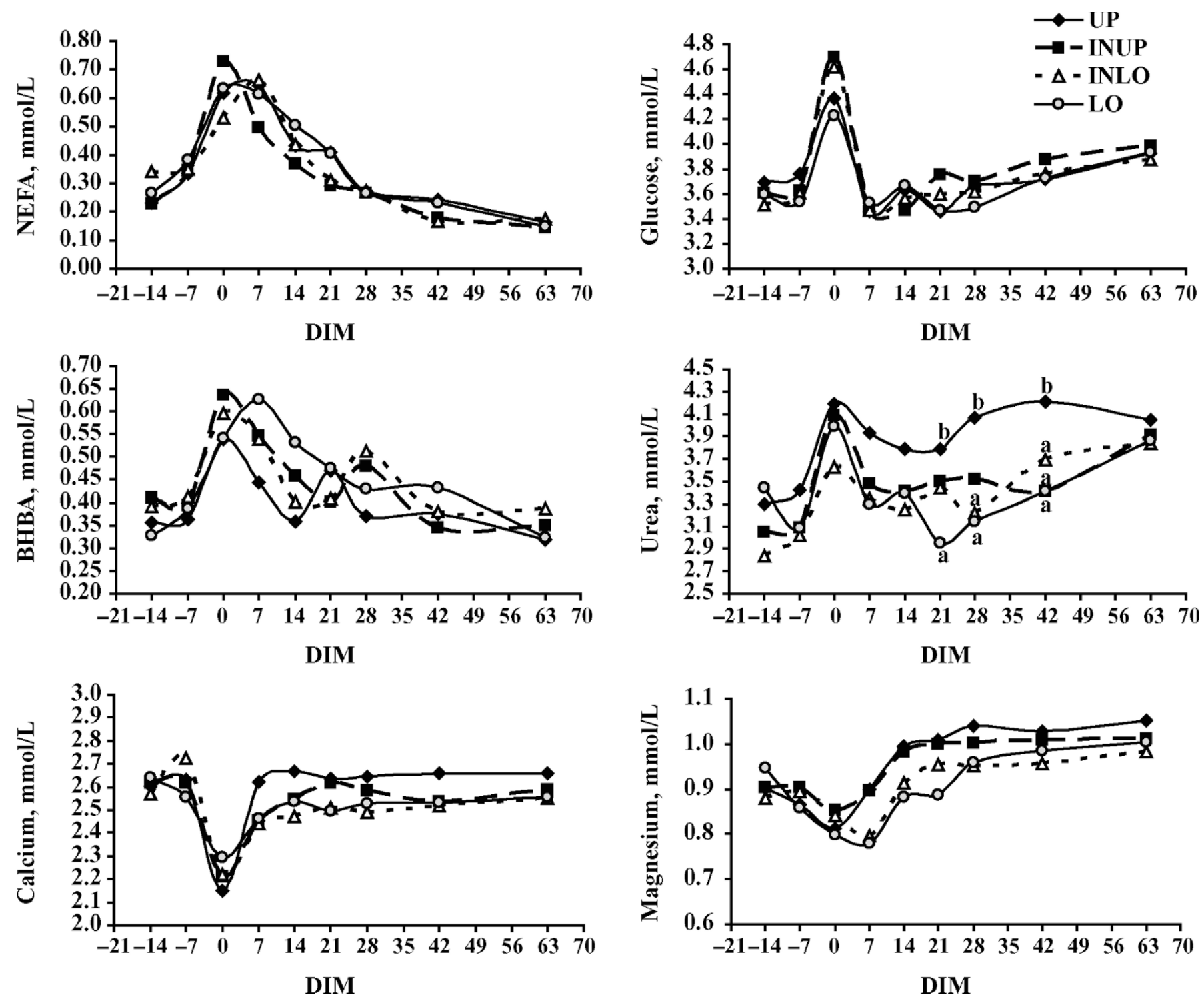

Figure 2. Patterns of NEFA (SEM $=0.06)$, glucose (SEM $=0.36)$, BHBA $(\mathrm{SEM}=0.08)$, urea $(\mathrm{SEM}=0.12)$, calcium $(\mathrm{SEM}=0.03)$, and magnesium ( $S E M=0.02$ ), in plasma of cows grouped in quartiles according to baseline paraoxonase activity observed during the first month of lactation: upper (UP), upper intermediate (INUP), lower intermediate (INLO), and lower (LO) quartile. ${ }^{\text {a-c }}$ A significant difference between groups at the same DIM is shown by letters; $P<0.05$.

\section{PON and Inflammation}

Feingold et al. (1998) clearly demonstrated that PON activity in the serum and its hepatic mRNA level decrease during the acute phase response after LPS injection in male Syrian hamsters. Consequently, they concluded that $\mathrm{PON}$ is a negative acute phase protein. If this is the case, a cause for reduced PON activity could be an inflammatory condition; i.e., any serious disease. This is of enormous interest because inflammatory-like conditions are known to occur during the peripartum period in dairy cows (Cappa et al., 1989; Drackley et al., 2005), and typically are associated with a reduction in -APP (Fleck, 1989). Therefore, the PON reduction around parturition we observed could be due to a lower rate of synthesis in the liver, as occurs with -APP. It is likely that the reduction occurring at parturition in liver-derived HDL, which is a carrier for PON, plays a role in the availability of PON in the circulation, particularly before calving. Furthermore, apolipoprotein A, the basic protein for the synthesis of HDL, is considered a -APP, and thus the reduction in HDL could be caused by an inflammatory condition, as has been previously reported for total lipoproteins (Bertoni et al., 1989). 
Table 3. Frequency (\%) of cows with health problems observed during the first $30 \mathrm{~d}$ after parturition grouped in quartiles according to baseline paraoxonase activity observed during the first month of lactation: upper (UP), upper intermediate (INUP), lower intermediate (INLO), and lower (LO) quartile

\begin{tabular}{|c|c|c|c|c|c|c|}
\hline \multirow[b]{2}{*}{ Health problem ${ }^{1}$} & \multirow[b]{2}{*}{ Total } & \multicolumn{4}{|c|}{ Group } & \multirow[b]{2}{*}{$P$-value ${ }^{2}$} \\
\hline & & UP & INUP & INLO & LO & \\
\hline \multicolumn{7}{|l|}{ Frequency $^{3}$} \\
\hline At least 1 problem & 52.2 & 11.8 & 56.3 & 47.1 & 94.1 & $<0.001$ \\
\hline Serious inflammations ${ }^{4}$ & 40.3 & - & 37.5 & 47.1 & 82.3 & $<0.001$ \\
\hline \multicolumn{7}{|l|}{ Type of problem ${ }^{5}$} \\
\hline Dystocia & 3.0 & - & - & 5.9 & 5.9 & 0.57 \\
\hline Milk fever & 4.5 & - & 6.3 & - & 11.8 & 0.29 \\
\hline Retained placenta & 13.4 & - & 18.8 & 17.6 & 17.6 & 0.33 \\
\hline Metritis & 16.4 & - & 12.5 & 5.9 & 47.1 & $<0.001$ \\
\hline Lameness $^{6}$ & 9.0 & - & 6.3 & - & 23.5 & 0.025 \\
\hline Leg injuries and swelling & 7.5 & - & - & 17.6 & 11.8 & 0.13 \\
\hline Mastitis & 16.4 & 5.9 & 25.0 & 11.6 & 23.5 & 0.39 \\
\hline Digestive problems ${ }^{7}$ & 4.5 & 5.9 & 6.3 & - & 5.9 & 0.80 \\
\hline
\end{tabular}

${ }^{1}$ The data are from the first month of lactation.

${ }^{2}$ Overall group effect.

${ }^{3}$ Percentage of cows with at least 1 incidence.

${ }^{4}$ The data include cows with or without clinical symptoms identified according to high haptoglobin $(>0.3$ $\mathrm{g} / \mathrm{L}$ ) concomitantly with low milk yield (decrease $\geq 20 \%$ milk production).

${ }^{5}$ The data are reported as percentage of incidence of each problem among groups.

${ }^{6}$ Lameness includes abscess, pododermatitis circumscripta (ulcer), interdigital skin hyperplasia (corns), interdigital phlegmon (foot rot), digital dermatitis, and white line disease.

${ }^{7}$ The digestive problems include diarrhea and rumen acidosis.

In our study, which involved only 67 cows, the stratification of cows according to PON values during the first month of lactation seems to correspond quite well with grouping according to the frequency and seriousness of disease, as well as to inflammation status (Table 3). This was the case for haptoglobin (+APP; Figure 1), as well as -APP such as albumin, RBP as vitamin A, and total cholesterol (Table 2). The response of globulins, considered as an index of immunoglobulin production, confirms the difference in inflammatory state among the 4 groups (better in UP and worse in LO).

The correlations between PON and other plasma measures that appear particularly interesting include 1) the negative correlation with measurements that usually increase during inflammation: haptoglobin $(\mathrm{r}=$ $-0.39 ; P<0.001)$, an acute phase protein, and ROM ( $\mathrm{r}=$ $-0.33 ; P<0.001$; indices of the oxidative damages); 2 ) the positive correlation with measures that usually are reduced during inflammation: albumin $(\mathrm{r}=0.38 ; P<$ 0.001), lipoproteins (C-LDL, $\mathrm{r}=0.48$; total cholesterol, $\mathrm{r}=0.55 ; P<0.001)$, and carriers of vitamins $(\mathrm{r}=0.54$; $P<0.001$, RBP for vitamin A).

In other words, a plasma protein synthesized in the liver, such as PON, as well as many other proteins usually synthesized by the liver, is reduced when this organ is triggered to help the immune system during the inflammatory response (Fleck, 1989).
Our data suggest that inflammation may cause a shift in liver protein synthesis as described by Fleck (1989) and Gruys et al. (1998); they have observed that inflammatory conditions cause an increase in plasma levels of some acute phase proteins (e.g., haptoglobin), which is associated with a decrease in plasma levels of other proteins (e.g., RBP, lipoprotein, and albumin). Therefore, in an inflammatory state, the hepatic synthesis of some proteins (-APP) can be impaired, with a consequent impairment of liver function. This scenario is further supported by the reduction in bilirubin clearance; in fact, the bilirubinemia was increased at parturition (Figure 1), and the pattern of bilirubin was correlated with the PON changes after parturition $(r=$ $-0.42 ; P<0.001)$. The specific increase in bilirubin as a consequence of inflammation could be explained by the effect of IL-1, a proinflammatory cytokine, which inhibits the nuclear activator involved in the gene expression of key enzymes in bilirubin clearance and drug clearance in the liver (Assenat et al., 2004). The bilirubinemia typically increases around parturition in cows and in other mammals. The abnormal level of bilirubin was observed for a shorter period than for albumin, vitamin A, and lipoproteins (as well as PON). This suggests that liver function impairment occurred only during the inflammatory phase and that the recovery of normal values of the blood indices takes different times. 

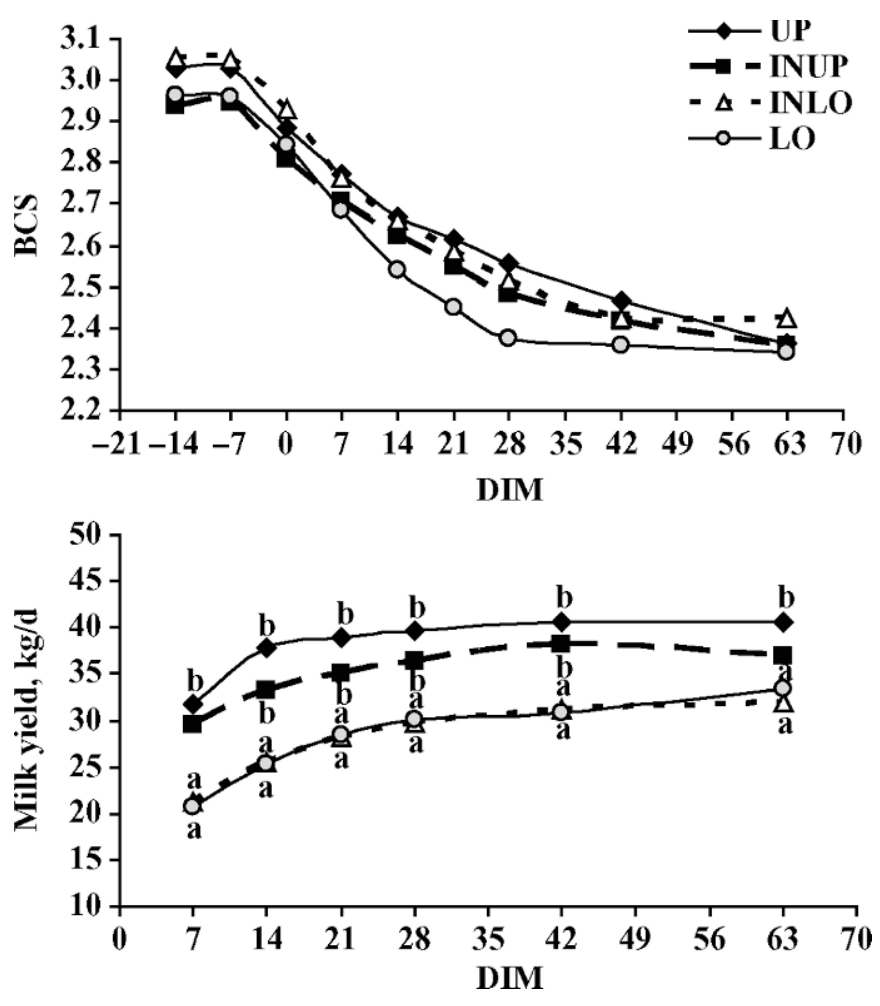

Figure 3. Body condition score $(\mathrm{SEM}=0.16)$ and milk yield $(\mathrm{SEM}=$ 3.8) during the first month of lactation in cows grouped in quartiles according to baseline paraoxonase activity observed during the first month of lactation: upper (UP), upper intermediate (INUP), lower intermediate (INLO), and lower (LO) quartile. ${ }^{a-c}$ A significant difference between groups at the same DIM is shown by letters; $P<0.05$.

\section{Standardized PON Activity (PON/C-HDL)}

A change in the PON/C-HDL ratio between early and advanced lactation cows was observed by Turk et al. (2004) as a consequence of PON change. In contrast, our results showed a change in the PON/C-HDL ratio as a consequence of PON and HDL variations. The reason for the differences between these outcomes could be associated with the lactation period studied; cholesterol and its fractions are greatly modified around parturition (Bertoni et al., 1984; Cappa et al., 1989). According to our experience (Bertoni et al., 1984), the lowest values of cholesterol are observed around parturition; afterwards, the cholesterol levels gradually increase and reach a maximum around 90 to 120 DIM. Because cholesterol is affected mainly by lipoproteins in blood, its variation depends largely upon the amount of mobilized lipids that are reesterified and included in very low density lipoprotein by the liver (Puppione, 1978). The decrease in PON/HDL after parturition in our study, except in the UP group, suggests a larger and more rapid decrease in blood PON concentrations than HDL concentrations in groups LO, INLO, and INUP. This might be due to the higher sensitivity of PON to inflammatory-like conditions compared with HDL. Inflammation could cause a greater decrease in PON synthesis than in HDL synthesis in the liver, as suggested by Feingold et al. (1998).

\section{PON Level and Oxidative Status}

Our data show a correlation between PON and ROM during the first $2 \mathrm{wk}$ of lactation $(\mathrm{r}=-0.24, P<0.006)$. Turk et al. (2005) suggested that lower PON levels lead to a reduction of antioxidative protection during the early postpartum period. Nonetheless, despite Aviram and Rosenblat's (2004) suggestions, a direct effect of ROM on PON activity remains to be determined. It must be emphasized that the reduction in PON in the present study occurred along with the inflammatory condition, and this last can directly cause a reduction in liver PON and HDL synthesis (both being -APP). Furthermore, an inflammatory response is a cause of increased oxidative stress, which could directly contribute to the PON reduction.

\section{Other Changes Related to PON Levels}

The retrospective stratification of cows according to PON activity during the first month of lactation allows the separation of animals with greater or fewer health problems (Table 3). Furthermore, the rise of plasma haptoglobin and globulin concentrations during the first 2 wk after parturition in cows with lower PON activity confirmed the presence of an inflammatory response. The overall data confirm the presence of inflammatory conditions, with or without clinical symptoms, during the transition period, and these may justify the lower plasma level of PON; therefore our data agree with the results obtained by Mackness et al. (1998).

Cows in the UP group exhibited the best health status, which explains the high mature equivalent milk yield and the less pronounced negative energy balance with respect to the other groups (Figure 3).

\section{CONCLUSIONS}

The baseline plasma PON (Li-heparin) activity in dairy cows is slightly lower in the dry period, as is the case for most enzymes originating in the liver. Around parturition, PON remains unchanged or is reduced in response to the inflammatory conditions; its level is negatively correlated with haptoglobin (+APP) and positively correlated with albumin, vitamin A as an index of retinol binding protein, and cholesterol as an index of lipoproteins (-APP). The reduction in PON levels 
and these correlations may be explained partly by the binding of PON to HDL; nevertheless, the more pronounced decrease in PON concentrations, compared with HDL concentrations, suggests that PON may be considered a -APP. Thus, reduction of PON in cows around parturition may be an index of a lower level of liver function, which does not mean lower liver activity. It was demonstrated that the liver simultaneously produces other proteins; for example, the +APP, whereas the cell damage indices (aspartate aminotransferase and GGT) did not significantly change.

Nevertheless, concentrations of PON and many other -APP remain lower in the plasma for a longer period with respect to the real liver impairment, as suggested by the bilirubin level that returned to basal values 2 to 3 wk after parturition, in tandem with the reduction in the inflammatory condition shown by haptoglobin. This suggests a cautious recourse to several indices of liver function; however, the more prolonged low level of PON (as well as albumin, RBP, etc.) can be useful for estimating the seriousness of problems that occurred long before the blood check. Furthermore, particularly for PON, which defends the animal against oxidative stress, a longer period with lower concentrations may increase the risk of oxidative damage, particularly at the lipoprotein level. Thus, the inflammatory phenomena may have a double negative effect: an increase in oxidative stress, and a reduction in the efficacy of the antioxidant systems, such as PON.

Finally, the positive relationship between PON (as a -APP) and milk production underlies the importance of preventing inflammation during the transition period. It is necessary to have a high liver function during the first month of lactation to obtain high performance in dairy cows; in other words, the liver should be engaged in producing the usual proteins and enzymes involved in its functions without any disturbance that might be a consequence of a stimulated production of $+\mathrm{APP}$.

These results do not answer all the questions about PON in dairy cows; more data are required. However, baseline plasma PON seems a promising diagnostic index for identifying the early lactating cows whose usual liver functions may be impaired. The cows diagnosed with low PON, that is, those more affected by inflammatory problems, can be treated to accelerate their recovery; thus, the liver function may be improved so that they can face the critical metabolic demands after parturition.

\section{ACKNOWLEDGMENTS}

The authors acknowledge R. J. van Saun (Department of Veterinary and Biomedical Science, Penn State
University) and J. J. Loor (Department of Animal Sciences, University of Illinois at Urbana-Champaign) for careful and critical reading of the manuscript.

\section{REFERENCES}

Ametaj, B. N., B. J. Bradford, G. Bobe, R. A. Nafikov, Y. Lu, J. W. Young, and D. C. Beitz. 2005. Strong relationship between mediators of the acute phase response and fatty liver in dairy cows. Can. J. Anim. Sci. 85:165-175.

Assenat, E., S. Gerbal-Chaloin, D. Larrey, J. Saric, J. M. Fabre, P. Maurel, M. J. Vilarem, and J. M. Pascussi. 2004. Interleukin $1 \beta$ inhibits CAR-induced expression of hepatic genes involved in drug and bilirubin clearance. Hepatology 40:951-960.

Aviram, M., and M. Rosenblat. 2004. Paraoxonases 1, 2, and 3, oxidative stress, and macrophage foam cell formation during atherosclerosis development. Free Radic. Biol. Med. 9:1304-1316.

Bertoni, G., M. G. Maianti, and V. Cappa. 1984. Variazioni nel metabolismo lipidico e glucidico nelle fasi terminali della gravidanza ed iniziali della lattazione nelle bovine. Pages 223-236 in Proc. Società Italiana di Buiatria, Modena, Italy. Emilio Bono, Torino, Italy.

Bertoni, G., F. Piccioli-Cappelli, and L. Calamari. 1989. Effects of endotoxins and histamine on the blood levels of some minerals. Pages 87-90 in Proc. Int. Meet. Mineral Nutr. Mineral Requirements Rumin., Kyoto, Japan. Showado Insatsu, Kyoto, Japan.

Bertoni, G., E. Trevisi, L. Calamari, and M. Bionaz. 2006. The inflammation could have a role in the liver lipidosis occurrence in dairy cows. Pages 157-158 in Production Diseases in Farm Animals, 12th Int. Conf. N. Joshi and T. H. Herdt, ed. Wageningen Academic Publ., Wageningen, the Netherlands.

Bertoni, G., E. Trevisi, L. Calamari, and R. Lombardelli. 1998. Additional energy and protein supplementation of dairy cows in early lactation: Milk yield, metabolic-endocrine status and reproductive performances. Zootec. Nutr. Anim. 24:17-29.

Bin Ali, A., Q. Zhang, Y. K. Lim, D. Fang, L. Retnam, and S. K. Lim. 2003. Expression of major HDL-associated antioxidant PON-1 is gender dependent and regulated during inflammation. Free Radic. Biol. Med. 34:824-829.

Calamari, L., M. G. Maianti, C. Carasi, and G. Bertoni. 1994. Lo stato di fase acuta ed i riflessi sulla funzionalità epatica. Pages 1215-1218 in Proc. XVIII World Buiatric Congress, Vol. II, Bologna, Italy. Editografica, Bologna, Italy.

Cappa, V., E. Trevisi, and G. Bertoni. 1989. Variazioni ematiche e produttive nel $1^{\circ}$ mese di lattazione in bovine di allevamenti con o senza problemi "post-partum". Zoot. Nutr. Anim. 15:645-660.

Costa, L. G., R. J. Richter, W.-F. Li, T. Cole, M. Guizzetti, and C. E. Furlong. 2003. Paraoxonase (PON 1) as a biomarker of susceptibility for organophosphate toxicity. Biomarkers 8:1-12.

Drackley, J. K., H. M. Dann, G. N. Douglas, N. A. Janovick Guretzky, N. B. Litherland, J. P. Underwood, and J. J. Loor. 2005. Physiological and pathological adaptations in dairy cows that may increase susceptibility to periparturient diseases and disorders (invited review). Ital. J. Anim. Sci. 4:323-344.

Feingold, K. R., R. A. Memon, A. H. Moser, and C. Grunfeld. 1998. Paraoxonase activity in the serum and hepatic mRNA levels decrease during the acute phase response. Atherosclerosis 139:307-315.

Ferré, N., J. Camps, E. Prats, E. Vilella, A. Paul, L. Figuera, and J. Joven. 2002. Serum paraoxonase activity: A new additional test for the improved evaluation of chronic liver damage. Clin. Chem. 48:261-268.

Fleck, A. 1989. Clinical and nutritional aspects of changes in acutephase proteins during inflammation. Proc. Nutr. Soc. 48:347-354.

Gruffat, D., D. Durand, Y. Chilliard, P. Williams, and D. Bauchart. 1997. Hepatic gene expression of apolipoprotein B100 during early lactation in underfed, high producing dairy cows. J. Dairy Sci. 80:657-666.

Gruys, E., M. J. M. Toussaint, W. J. M. Landman, M. Tivapasi, R. Chamanza, and L. van Veen. 1998. Infection, inflammation and 
stress inhibit growth: Mechanisms and non-specific assessment of the processes by acute phase proteins. Pages 72-87 in Production Diseases in Farm Animals. T. Wensing, ed. Wageningen Press, Wageningen, the Netherlands.

Itoh, H., K. Tamura, Y. Motoi, and F. Kawawa. 1997. Serum apolipoprotein B-100 concentrations in healthy and diseased cattle. J. Vet. Med. Sci. 59:587-591.

James, R. W., and S. P. Deakin. 2004. The importance of high-density lipoproteins for paraoxonase-1 secretion, stability, and activity. Free Radic. Biol. Med. 12:1986-1994.

Mackness, M. I. 1998. Why plasma should not be used to study paraoxonase. Atherosclerosis 136:195-196.

Mackness, B., P. N. Durrington, and M. I. Mackness. 1998. Human serum paraoxonase. Gen. Pharmacol. 31:329-336.
Puppione, D. L. 1978. Implications of unique features of blood lipid transport in the lactating cow. J. Dairy Sci. 61:651-659.

Tennant, B. C. 1997. Hepatic function. Pages 327-352 in Clinical Biochemistry of Domestic Animals. 5th ed. J. J. Kaneko, J. W. Harvey, and M. L. Bruss, ed. Academic Press, London, UK.

Turk, R., D. Juretic, D. Geres, N. Turk, B. Rekic, V. Simeon- Rudolf, M. Robic, and A. Svetina. 2005. Serum paraoxonase activity in dairy cows during pregnancy. Res. Vet. Sci. 79:15-18.

Turk, R., D. Juretic, D. Geres, N. Turk, B. Rekic, V. Simeon-Rudolf, and A. Svetina. 2004. Serum paraoxonase activity and lipid parameters in the early postpartum period of dairy cows. Res. Vet. Sci. 76:57-61.

Zech, R., R. M. Severin, J. M. Chemnitius, and K. Nebendahl. 1999. Paraoxonase polymorphism in rabbits. Chem. Biol. Interact. 120:283-288. 